\title{
Interdisciplinary care in the treatment of orofacial pain. Case report
}

\author{
Atendimento interdisciplinar do tratamento da dor orofacial. Relato de caso \\ Luci Mara França Correia ${ }^{1}$, Juliana Wille Silva ${ }^{1}$, Henrique Lourenço da Costa Lima ${ }^{1}$, Michael Krakauer ${ }^{1}$
}

DOI 10.5935/2595-0118.20190053

\section{ABSTRACT}

BACKGROUND AND OBJECTIVES: The importance of interdisciplinary action has been increasingly recognized in the area of health due to the global effect that has on the various symptoms of the patient. Interdisciplinarity is possible when professionals allow the exchange of knowledge through clinical meetings and jointly follow-up of the case. The objective of this study was to document the interdisciplinary care of patients with orofacial pain symptoms and comorbidities.

CASE REPORT: Female patient, 48 years old, diagnosed with muscular temporomandibular disorder and oral opening limitation, labyrinthine cervicalgia, tinnitus, sleep disorder, eating disorders and anxiety after evaluation with an odontologist, otorhinolaryngologist, physiotherapist, acupuncturist, psychologist and nutritionist. The 1-year follow-up with monthly visits with the dentist and nutritionist, and biweekly visits with a psychologist, physiotherapist, and acupuncturist showed symptoms control with total remission of the orofacial pain, cervicalgia, labyrinthitis. Tinnitus did not improve in the sense of frequency that remained constant, but according to the patient, there was an improvement in the adaptation to tinnitus in places with excessive noise, thus allowing a better social interaction. Nutrition and psychology made a great contribution to self-esteem and social routine as well as to seek for a better quality of life.

CONCLUSION: The interdisciplinary work promoted a global approach to the patient's symptoms.

Keywords: Chronic pain, Comorbidity, Interdisciplinary, Orofacial pain.

\section{RESUMO}

JUSTIFICATIVA E OBJETIVOS: A importância da ação interdisciplinar tem sido cada vez mais reconhecida na área da saúde, pelo efeito global que exerce sobre os diversos sintomas da paciente. A interdisciplinaridade é possível quando os profissionais permitem a troca do conhecimento através de reunióes clínicas e acompanhamento em conjunto do caso. O objetivo deste estudo foi documentar o atendimento interdisciplinar de paciente que apresentava sintoma da dor orofacial e comorbidades.

RELATO DO CASO: Paciente do sexo feminino, 48 anos, diagnosticada com disfunçáo temporomandibular muscular e limitação de abertura bucal, cervicalgia labirintite, zumbido, distúrbio do sono, distúrbios alimentares e ansiedade após avaliação com odontólogo, otorrinolaringologista, fisioterapeuta, acupunturista, psicólogo e nutricionista. O acompanhamento de 1 ano com consultas mensais na área da odontologia e nutrição e consultas quinzenais na área de fisioterapia, acupuntura e psicologia demonstrou controle dos sintomas com remissão total da dor orofacial, cervicalgia, labirintite. $\mathrm{O}$ zumbido não teve melhora no sentido de frequência que permaneceu constante, mas segundo a paciente houve melhora na adaptação ao zumbido em lugares com excesso de barulho, permitindo assim melhor interação social. A nutrição e a psicologia tiveram uma grande contribuiçáo na autoestima e rotina social bem como na busca por melhor qualidade de vida.

CONCLUSÃO: O trabalho interdisciplinar promoveu uma abordagem global dos sintomas da paciente.

Descritores: Comorbidade, Dor crônica, Dor orofacial, Interdisciplinaridade.

\section{INTRODUCTION}

According to the American Academy of Orofacial Pain (AAOP), temporomandibular dysfunction (TMD) is defined as a set of clinical signs involving the muscles of mastication, temporomandibular joint (TMJ) and associated structures ${ }^{1}$. The most frequent symptoms are muscle fatigue, pain in the face, in the TMJ, headache, and pain in the ears, limitation, and deviation of mandibular movements, and many cases may also present symptoms in the cervical region ${ }^{2}$.

The close relationship between orofacial and cervical pain has been the subject of study by many researchers ${ }^{2-4}$. Several studies have shown the convergence of different types of nociceptive afferents to the caudal subnucleus and can act together as a functional unit to process nociceptive information of craniofacial and cervical tissues, including deep craniofacial tissues, explaining the close relationship between painful symptoms in the facial and cervical region ${ }^{4}$. 
The literature indicates that hyperexcitability in the central nociceptive system may favor the rise or maintenance of chronic pain in TMD cases. It is also possible to identify that the increased sensitivity of the mastication and cervical muscles may be related to the symptoms of cervical pain 5 .

In addition to the relationship with cervical pain, orofacial pain is closely linked with psycho-emotional aspects, which may act as predisposing factors (which increases the risk of TMD) and/ or perpetuating factors (which interfere with disease control) ${ }^{6,7}$. This relationship between psychological factors and TMD is so relevant that the Diagnostic Criteria for Temporomandibular Dysfunction (DC/TMD) addresses 2 axes of assessment, one for physical factors called axis 1 , and the one that assesses the intensity and severity of chronic pain and the levels of psychological symptoms with a biopsychosocial approach called axis 2 . The reliability of DC/TMD has already been tested and considered satisfactory in adult populations ${ }^{8}$.

When the mind gets sick, the body gets sick, and the influences of this mind-body relationship are very well evaluated by traditional Chinese medicine (TCM). In the Western world, health is often understood as the absence of disease. TCM considers the balance of body, mind, and spirit. Any imbalance of this integral unity causes disease, so the person must maintain a harmonious relationship within itself and everything around'.

TCM assesses the internal and external pathogenic factors using metaphorical language because of its historical and cultural origin and cannot be mistaken for the pathophysiology of contemporary medicine. Emotions such as fear, panic, anger, worry, joy (excessive excitement), sadness, and melancholy are all capable of generating physiological problems ${ }^{10}$. For example, emotions such as anger and fear affect the liver and kidney, respectively.

Knowing the close relationship between these various areas and the possible comorbidity among all symptoms, there is a need for an interdisciplinary approach to the treatment of TMD and all the variables involved ${ }^{11}$. Given the current time and relevance of the topic, the present study aimed to describe an interdisciplinary approach relating the areas of dentistry, otorhinolaryngology, physiotherapy, psychology, acupuncture, and nutrition in the treatment of orofacial pain and other concomitant symptoms such as neck pain, labyrinthitis, tinnitus, anxiety, stress and low self-esteem.

\section{CASE REPORT}

A 48-year-old female patient sought TMD and Orofacial Pain evaluation with symptoms of facial fatigue, pain during mandibular movement, bilateral tinnitus more intense on the left side, also with cervical pain and labyrinthitis. The patient had a history of treatment for each of these complaints individually, with limited or short-term results. Treatment with labyrinthitis drugs, proposed by the otorhinolaryngology area and used during the last 30 months did not control the symptoms and labyrinthitis was daily with worsening moments throughout the day.

The patient underwent clinical evaluation according to the following instrument and protocol:

1. Completion of the clinical record to detail the main complaint, TMD pain characteristics (location, intensity, quality, du- ration, recovery, and worsening factors), presence of other painful conditions in the cervical region, headaches or other pains, as well as like medical background;

2. Application of AAOP was used for differential diagnosis with other conditions that may resemble TMD;

3. Use of the TMD (DC/TMD) questionnaire to diagnose myalgia with mouth opening limitation. The masseter (superficial and deep belly) and temporal muscles were evaluated as well as the pain referred to the facial region when the sternocleidomastoid, suboccipital and trapezius muscles were palpated;

4. Physiotherapist assessment focusing on manual therapy. The presence of pain on active movements and range of motion (ROM), pain on palpation of cervical muscles and postural alteration (protruding shoulders and head), and mobility restriction of the cervical and thoracic fascia were diagnosed;

5. Psychological evaluation after filling axis 2 of the RDC that showing the negative influence of pain, tinnitus, and labyrinthitis on their daily activities and social relationship, as well as anxiety and concern for their health;

6. Nutritional assessment focusing on issues of tinnitus, pain, overweight, low self-esteem, previous diagnosis of ulcerative colitis, and anal fissure. At the nutritional assessment it was identified obesity 1 (WHO), weighting $-81.5 \mathrm{~kg}$, height $-1.64 \mathrm{~m}$, body mass index $-30.3 \mathrm{~kg} / \mathrm{m}^{2}$, imbalance in nutritional intake, with exacerbated consumption of simple carbohydrates;

7. A diagnostic evaluation by TCM in patients with labyrinthitis and climacteric. TCM associates these complaints with a kidney deficiency;

8. Completion of the pain diary and verbal numerical scale since the first assessment to monitor the progression or decrease of the pain and other symptoms.

The interdisciplinary team held a meeting before the beginning of the care to share the diagnosis of each area and present the proposed treatment plan. It was agreed as follows: dentistry and nutrition - one visit per month, physiotherapy, acupuncture, and psychology visits - twice a month, and biweekly clinical meetings to monitor the evolution of each area and exchange information, if necessary, with the patient's consent.

The patient was asked to complete a pain diary containing information on the frequency and intensity of tinnitus, facial pain, neck pain, and labyrinthitis, as well as stress factors and sleep quality.

A TMD therapeutic protocol was initiated with myofascial trigger point inactivation (TPI) of the masseter, temporal and sternocleidomastoid muscles during the first four months, as well as guidance on diet, muscle exercise, and thermotherapy.

Concomitant with the dentistry work, physiotherapy sessions were initiated with manual myofascial release therapy and relaxation of the structures involved in the compensation and pain complex.

The treatment performed through manual therapy approached muscle spasm inhibition, connective tissue manipulation, myofascial release, and cervical joint mobilization.

The otorhinolaryngologist evaluated the labyrinthitis who diagnosed a chronic hearing loss. The drug to control the labyrinthitis was already being used for one year without satisfactory results. Acupuncture was then introduced to help with this symptom. In 
the first sessions, the patient noticed a difference in labyrinthitis and improved sleep quality and anxiety. By the fifth session, the labyrinthitis symptom was no longer constant, and there were reports of days without the complaint.

Psychology sessions took place every 15 days throughout the treatment. There was a worsening of the symptoms at two moments, directly related to stressful situations that emotionally unbalanced the patient, such as stressful situations at work, personal decisions, and self-perception of life. These situations were addressed by therapy, and with the patient's consent, the other professionals involved were informed at the biweekly clinical meetings, to conduct the case better.

The improvement of the symptoms was gradual and followed at each appointment by the verbal numerical scale and the patient's report.

The pain diary indicated $100 \%$ decrease in labyrinthitis, facial pain, and tension in the face and cervical region after nine months of treatment. Tinnitus did not improve in terms of volume reduction but reduced the patient's perception of discomfort caused to the patient's social activities or being in environments with noise or music.

Regarding nutrition, a menu was prescribed with nutritional adjustments to the profile and particularities presented by the patient.

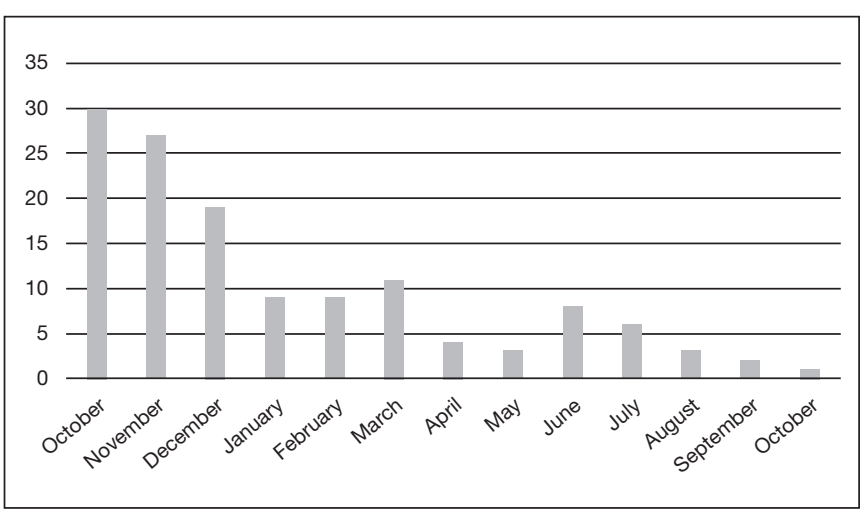

Figure 1. Tracking the frequency of labyrinthitis days from October 2017 to October 2018

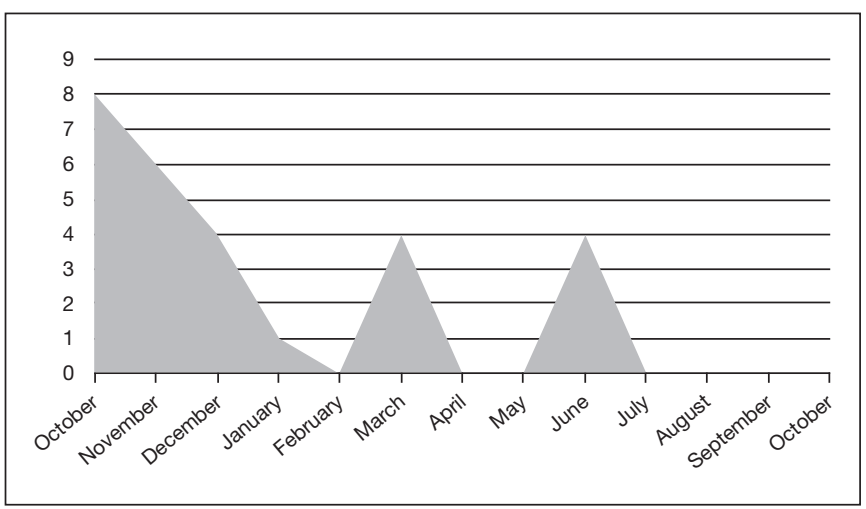

Figure 2. Symptoms of temporomandibular disorder, pain in the face, joint, opening limitation. Improvement in the first 4 months and 2 peaks of relapse related to emotional factors
In the eight months of nutritional follow-up, she had 100\% improvement in pain, metabolic profile, food choice, and intake. She lost $7.7 \mathrm{~kg}$, which improved her self-esteem, motivation, and mood, with more physical and social activities in daily life. There was a volume reduction in tinnitus at only one moment of the nutritional treatment when specific supplementation started. However, it returned to the previous state. On the other hand, auditory perception does not bother her as much as before the interdisciplinary treatment.

\section{DISCUSSION}

Pain is one of the most common reasons for seeking health professionals, and TMD is one, which has shown a close relationship with several other comorbidities such as cervical pain and headache. All these dysfunctions may become chronic if not managed early on, causing physiopathological phenomena such as central sensitization and decreased the activity of the pain inhibitory system ${ }^{2}$. Current research has shown that the relationship of painful symptom in these various regions, when it occurs concomitantly, can be explained by the physiological mechanism of neuronal convergence ${ }^{2}$.

In this patient, the influence of emotional factors on the worsening of the condition during the 9-month follow-up was evident. Other authors have also found the psychological factor influencing pain ${ }^{6,7}$, especially muscle pain. In the Paiva Bertoli et al. study ${ }^{6}$, the relationship between anxiety and TMD was significant, in both muscle and joint TMD, in the reduced disc displacement, about $70 \%$ of the sample had moderate anxiety, and about $12 \%$ had high anxiety. One possible explanation for the relationship between TMD pain and anxiety may be that anxiety exacerbates the tension of the mastication muscle. The Alkhudhairy et al. study ${ }^{11}$ showed, using questionnaires, that habits and emotion were statistically significantly related as "jaw pain or stiffness when waking up, or clenching teeth" and "how often were you upset about something that happened unexpectedly? "or" have you had pain in your jaw, temple, ear, or in front of your ear" and "how many times have you been upset about something that happened unexpectedly ". This biopsychosocial evaluation in the treatment of TMD is so important that DC-TMD included it in the axis II of psycho-emotional aspects evaluation. Dworkin et al. ${ }^{8}$ showed that severe levels of somatization could potentially mislead the interpretation of the clinical examination of axis I, influencing the diagnosis and control of TMD.

In this report, TMD was controlled after fourth months of treatment, with total remission of symptoms in the fifth month. However, there were two episodes of worsening after stabilization of pain and symptoms of facial tension and limitation of mouth opening, clearly related to emotional stress factors. New TPI sessions were held, and the emotional picture controlled, and symptoms disappeared.

According to TCM, the kidney physiology is also related to willpower or desire to accomplish something. The treatment greatly contributed to helping the patient to change her habits because, at each step, it promoted body self-perception, emotional control, and determined the physical balance. 
As shown by Tai ${ }^{9}$, healing cannot be isolated by a specific physical method. Instead, any disease must be understood and treated in a holistic and balanced manner, as proposed by $\mathrm{TCM}^{13}$.

Among the factors associated with tinnitus, metabolic changes may impair the functioning of the inner ear. This is because hair cell lesions resulting from peripheral insulin resistance, changes in glucose metabolism, hyperinsulinemia, hyperlipidemic diet, ATP availability, and oxygen levels can modify cochlear homeostasis ${ }^{12}$. Nutritional monitoring, metabolic adjustment, and weight loss have contributed to improve the quality of life and self-esteem, inner ear functioning, helping to control labyrinthitis. Also, the inactivation of the trigger points during muscle TMD sessions, provided the relaxation of the ear and mastication muscles, contributing to the improvement of the tinnitus symptoms.

This is just a case report, with uncontrolled variables, but the interesting thing to highlight in this study is the fact that the patient had previously sought several treatments for several years, from isolated, non-simultaneous areas, which had very little or almost no results, so much so that the pain returned soon. When therapy became interdisciplinary and concomitant among all areas, the control was obtained, and the patient was able to achieve a relevant psycho-emotional balance and important body self-knowledge that keeps her healthy and with a good quality of life.

\section{CONCLUSION}

The interdisciplinary work allowed for a global approach to the patient's symptoms.

\section{REFERENCES}

1. American Academy of Orofacial Pain. General assessment of the orofacial pain patient. In: de Leeuw R, Klasser GD, editors. Orofacial pain - guidelines for assessment, diagnoses and management. 5th ed. Chicago: Quintessence; 2013. 23-46p.

2. Costa YM, Conti PC, de Faria FA, Bonjardim LR. Temporomandibular disorders and painful comorbidities: clinical association and underlying mechanisms. Oral Surg Oral Med Oral Pathol Oral Radiol. 2017;123(3):288-97.

3. De Wijer A. Neck pain and temporomandibular dysfunction. Ned Tijdschr Tandheelkd. 1996;103(7):263-6.

4. Sessle BJ, Hu JW, Amano N, Zhong G. Convergence of cutaneous, tooth pulp, visceral, neck and muscle afferents onto nociceptive and non-nociceptive neurones in trigeminal subnucleus caudalis (medullary dorsal horn) and its implications for referred pain. Pain. 1986;27(2):219-35.

5. Chaitow L. Terapia Manual para disfunçẫo fascial. Porto Alegre: Artmed; 2017.

6. de Paiva Bertoli FM, Bruzamolin, de Almeida Kranz GO, Losso EM, Brancher JA, de Souza JF. Anxiety and malocclusion are associated with temporomandibular disorders in adolescents diagnosed by RDC/TMD. A cross-sectional study. J Oral Rehabil. 2018;45(10):747-55.

7. Reiter S, Eli I, Mahameed M, Emodi-Perlman A, Friedman-Rubin P, Reiter MA, Winocur E. Pain catastrophizing and pain persistence in temporomandibular disorder patients. J Oral Facial Pain Headache. 2018;32(3):309-20.

8. Dworkin SF, Sherman J, Mancl L, Ohrbach R, LeResche L, Truelove E. Reliability, validity, and clinical utility of the research diagnostic criteria for temporomandibular disorders axis II scales: depression, non-specific physical symptoms, and graded chronic pain. J Orofac Pain. 2002;16(3):207-20.

9. Tai MCT. An oriental understanding of health. Tzu Chi Med J. 2012;24:92e-5.

10. Souza EF, Luz MT. Análise crítica das diretrizes de pesquisa em medicina chinesa. Hist Ciênc Saúde - Manguinhos. 2011;18(1):155-74.

11. Alkhudhairy MW, Al Ramel F, Al Jader G, Al Saegh L, Al Hadad A, Alalwan T, et al. A self-reported association between temporomandibular joint disorders, headaches, and stress. J Int Soc Prev Community Dent. 2018;8(4):371-80.

12. Oliveira M, El Hassam S. Correlaçấo entre os sintomas auditivos e vestibulares no período pré e pós-cirurgia bariátrica. Com Ciências Saúde. 2014;25(1):45-56.

13. Ximenes CSX, Lobăo P, Lobo JS. Medicina Tradicional Chinesa: Fundamentos em Medicina Erval Chinesa e Formulação no Síndroma de Estagnação do Qi. Dissertação do $2^{\circ}$ Ciclo de Estudos conducente ao Grau de Mestre em Tecnologia Farmacêutica. repositorio-aberto.up.pt. Abril-2014. 